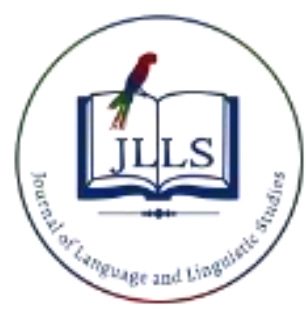

Available online at www.jlls.org

JOURNAL OF LANGUAGE AND LINGUISTIC STUDIES

ISSN: $1305-578 \mathrm{X}$

Journal of Language and Linguistic Studies, 16(2), 684-710; 2020

\title{
A study on the punctuation knowledge levels of freshmen students
}

\section{APA Citation:}

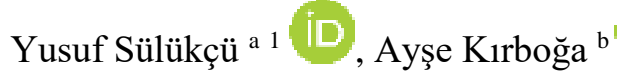 \\ ${ }^{a}$ Necmettin Erbakan University, Konya, Turkey \\ ${ }^{b}$ MoNE Kayall Middle School, Konya, Turkey
}

Sülükçü, Y. \& Kırboğa, A. (2020). A study on the punctuation knowledge levels of freshmen students. Journal of Language and Linguistic Studies, 16(2), 684-710.

Submission Date:20/08/2020

Acceptance Date:14/01/2020

\begin{abstract}
The present study was conducted to determine the use of punctuation marks by freshmen college Turkish language course students whose native language was Turkish. The study is a quantitative study where descriptive techniques were used. The study group included 204 students (157 female and 57 male students). An anonymous short story text that did not include any punctuation marks was used as the data collection instrument. The original text included 8 punctuation marks used in different parts of the text. The data were obtained by asking students to rewrite the text based on composition rules and including the missing punctuation marks. T-test, One-Way ANOVA, Tukey HSD tests available on IBM SPSS Statistics 22 software were used in data analysis. The study findings demonstrated that students made several mistakes in all punctuation marks. The period was the only punctuation mark used correctly by the majority of students. The students made the most mistakes when using the dash $(98.34 \%)$. Analysis of the findings based on student department, there was a difference in the use of exclamation marks only between PDR I. instruction 1/B and PDR II instruction 1/B classes. A significant difference was determined favoring the female students only between the use of quotation marks based on gender.
\end{abstract}

(C) 2020 JLLS and the Authors - Published by JLLS.

Keywords: punctuation marks; freshmen students; the punctuation Knowledge levels; writing skills; Turkish language instruction.

\section{Introduction}

As is known, individuals use verbal and written expression for communication. Writing is one of the most important instruments that individuals use to communicate with each other and transfer information to future generations. There are certain signs utilized to facilitate and improve the comprehension of the texts, and these signs are called the punctuation marks. Punctuation marks are used to differentiate elements of the sentence, embedded sentences, dependent sentences and parenthetical sentences, and to identify the emphasis, intonation and pauses in a sentence. When reading

\footnotetext{
${ }^{1}$ Corresponding author. Tel.: +90-332-323-8220

E-mail address: ysulukcu@erbakan.edu.tr
} 
an article, punctuation marks guide the reader like traffic signs (Hengirmen, 2007). We utilize punctuation to clarify the written expression using commas, semi colons, etc. (Baron, 2001)

In order to demonstrate the case better, it was decided that the study should be conducted with students who were secondary education graduates and who were admitted to the college due to their achievements in the university entrance exam and with higher knowledge levels. Because according to statistical data, among the 2,260.273 candidates who were secondary education graduates and took the university entrance exam, 496,616 were not able to pass the 150-point threshold, 41,281 candidates were not able to score 100 points or over (CNNTurk.com, 2019). It was considered that findings obtained with better students would more convincing for the solution of the problem. The study aimed to determine whether university students in Turkey used the punctuation marks accurately and to determine in which punctuation marks the students made the highest mistakes in Turkey based on the abovementioned study objectives. A brief history of punctuation marks is provided before proceeding to the findings and conclusion sections in the study.

\subsection{Literature review}

According to available manuscripts, writing lacked phenomena such as stopping, pausing, raising or lowering the tone, which clarified or changed the meanings of the sounds in ancient times. Thus, there were difficulties in reading and comprehension of the manuscripts. People investigated ways to overcome these problems using various marks. Thus, the first examples of the current punctuation marks began to emerge.

Punctuation existed since the invention of writing, albeit not in the current sense. Researchers claimed different perspectives about the emergence of punctuation marks and why they were initially used. Saenger (1997) argued that punctuation marks were initially used to identify the points where the reader needed to pause. Yildiz (2003) reported that Aristarkhos (310-230 BC) proposed certain punctuation marks in Alexandria, punctuation marks were used by proofreaders, Roman historian Suetonius (70-130) mentioned 21 punctuation marks in manuscripts written in BC. Huguet, (1946) and Egbert (1896) stated that punctuation marks were used to separate sections of expressions and sections in a manuscript (Cited by Wingo, 1972). Atasoy (2010) argued that in ancient times, the need to proofread the texts reproduced by copyists arose, and proofreaders called diortotai were employed in order to edit the completed works and these individuals started to use punctuation marks.

According to Edward Maunde Thompson (1912), the punctuation marks used in Latin were adapted from the Greek punctuation system and called 'distinctio finalis', 'subdistinctio', and 'distinctio media'. However, in the early texts where punctuation marks were used, there was no strict rule about how these would be used, where they would be used and for what purpose. In Western culture, modern punctuation marks were adopted in the sixth century, as Parkes (2016) demonstrated based on significant historical data. The punctuation marks were first standardized by William Caxton in the $15^{\text {th }}$ century in Europe. Caxton used three punctuation marks in English in his print shop: a horizontal line (/) to mark word groups, a colon (:) to mark different pauses in a sentence, and a period (.) to end the sentence. In $16^{\text {th }}$ century, Tyndale's Gospels improved the practice and tried to eliminate the uncertainties in Caxton's punctuation system (Vatkins, 2017). In the first half of the seventeenth century, colon, equal sign, semicolon and comma were used in the text to determine where to breathe. It was observed that commas and semicolons were used as alternatives for this task. At the end of the seventeenth century, attempts were made to determine certain rules for punctuation marks. Brenan was one of the first grammarians to claim that punctuation should not be an indicator of pauses and should be an integral part of sentence pattern (Vatkins, 2017). Baron (2001) also wrote that punctuation marks emerged in England to indicate 
pauses in Latin manuscripts, which were read aloud, however that role began to change in early eighteenth century and continued to change during the twentieth century.

Punctuation and accurate reading of texts have not been only an interest of Westerners but also the Muslims. They invented letters for the accurate reading of the Holy Quran for literate or illiterate individuals in Arabic. These letters were used based on the meaning of the phrase. These marks were used by Muhammad b. Tayfur es-Secâvendi (d: 560/1165) for the first time, and these marks with others that were introduced later were called "Secâvend" to honor his name (Çetin, 2013: 150). One of these marks is distinct from the marks used by Westerners since it tells the reader to continue without a pause.

Turks, on the other hand, used different marks at the end of a sentence and to interrupt the narration. On Orkhon inscriptions written in the $6^{\text {th }}$ century, the letters were not combined, and the words were separated from each other by a colon. Thus, punctuation was systematic. Gabain and Tekin reported that in Uighur texts written after the Orkhon inscriptions, period, two periods or more were used between two sentences and sometimes no marks were used. Maniheist reported that the same punctuation marks were used in manuscripts, however, the manuscripts differed from other texts, since red periods were used in the former (Gabain 1988: 11; Tekin 1997: 35).

Review of Arabic manuscripts would demonstrate that punctuation marks were not used in the texts and various methods were used to separate the texts or verses such as framing the text, using lines, using different colors, using titles and using floral ornaments. Şinasi was the first author to use punctuation marks in Ottoman Turkish in 1859 in his work "Poet's Marriage" (Oguzkan, 2005).

Today, punctuation marks and their use vary between countries. Furthermore, due to various requirements, new punctuation marks are introduced, and new functions are added to existing ones. Each country can set its own rules for punctuation. Punctuation and rules are determined by the Turkish Language Institution in Turkey (TDK).

These marks that are necessary to comprehend a manuscript are instructed beginning from the first grade in Turkey. In the first grade, "period, question mark, exclamation point, hyphen and apostrophe," in the second grade, "comma and dash," in the third grade "two periods and quotation marks," in the fourth grade, "parenthesis, ellipsis, slash," in the fifth grade, "semicolon and bracket," a total of 14 punctuation marks are instructed in primary education (MEB, 2018). In $6^{\text {th }}, 7^{\text {th }}$ and $8^{\text {th }}$ grades, different functions of these signs are instructed and reinforced.

Punctuation marks are of great importance in order to comprehend the meaning of a written expression. Therefore, these marks should be instructed well, and the students should use these marks correctly. However, even after completing the high school and passing the university admission exam, the students make several punctuation mistakes in writing. If they make mistakes when using the punctuation marks, these mistakes should be identified, and possible solutions should be investigated.

Various studies have been conducted to examine the problems of punctuation marks. Ar1 and Keray (2012), in their study with 8th grade students, found that students made fewer mistakes in multiple choice questions and more mistakes in dictation method. Arthur N. Applebee, Judith A. Langer, and I. V. Mullis (1987) found in their study on 9, 13 and 17 year old students that $25 \%$ of 9-year-old children did not make any mistakes and the error rate decreased with increasing age. Ozkar and Izci (2013) examined the relationship between 5th grade students' reading attitudes and punctuation marks and found a significant relationship between reading attitudes and punctuation marks. Karagul (2010) investigated the use of punctuation marks by the students and found that the students could not reach the desired level in the curriculum. Avc1 (2006), in a study that investigated the punctuation mistakes made by 8th grade students, reported that students made several punctuation mistakes. According to Yildırım and Uludag (2016) Secondary School 5-8. The students in the classes do not have enough skills in punctuation. 
Literature review demonstrated that there were no college level studies on punctuation marks in Turkish language. The present study aimed to determine the status of freshmen college students on punctuation marks and to investigate in which punctuation marks the students made the highest number of mistakes. The present study is considered significant since it aimed to determine the status of Turkish education system in the instruction of punctuation marks.

\subsection{Research questions}

The problem statement of the study was determined as follows "What is the level of punctuation mark use among the freshmen college students?" Furthermore, it was investigated whether the use of punctuation marks differed between the students based on their department and gender.

\section{Method}

In the study, the student data were converted into numbers, and the quantitative method was used to render more valid and reliable findings, and the qualitative method was used to interpret the data. Since punctuation marks are a part of the text, document analysis technique was used to collect the study data and description technique was used in interpretation. The technique, also called documentary observation, was defined by Rummel (1968) as the "document method." Best described the technique as the systematic review of existing records or documents as data resources (1959).

\subsection{Participants}

The study group included 204 freshmen students attending the Department of Turkish Language Education at Necmettin Erbakan University. Purposive sampling and cluster sampling methods were used since students in verbal departments were selected. Since the university entrance scores differed between the first education and second education students, students in both education systems in the same department were included in the study in order to analyze whether there was a correlation between university entrance scores and accurate use of punctuation marks. The study population included freshmen college students; thus, the study area was selected as the faculty where the author was employed based on the convenience principle. The study group included 147 female and 57 male students. The gender bias was due to the fact that the ratio of female students to male students was 3 to 1 in the department of study. The gender variable was selected to determine whether there was a difference between the adaptation of verbal skills to writing skills of the female students, who could use the pauses in verbal communications better than male students and utilize verbal communication more than males in general, and male students. Presence of a significant difference based on the gender variable would allow the development of education based on gender differences.

Table 1. Study Group

\begin{tabular}{ccccccc}
\hline & Turkish & PCG I. 1/A & PCG I. 1/B & PCG II. 1/A & PCG II. 1/B & Total \\
\hline Female & 27 & 34 & 28 & 26 & 32 & 147 \\
Male & 12 & 13 & 8 & 14 & 10 & 57 \\
Total & 39 & 47 & 36 & 40 & 42 & 204 \\
\hline
\end{tabular}




\subsection{Instrument}

As a data collection instrument, an anonymous text in Turkish that included 47 punctuation marks; 12 periods, 18 commas, 1 question mark, 1 exclamation point, 3 quotation marks, 5 double periods, 1 semi colon, and 6 dashes was selected. The text was reviewed by language experts to correct original punctuation errors.

\subsection{Data collection procedures}

Before the distribution of the text to the students, all text was rewritten in lowercase letters and all punctuation marks and paragraphs were removed. The manuscript was then distributed to the students and the students were asked to edit the text based on essay rules, paying attention to punctuation and spelling. Thus, a single text was used to ensure reliability, and freedom was ensured by allowing the student to edit the text with controlled writing. The students were allowed to edit the manuscript in 1 hour and the manuscripts edited by the students were collected at the end of the hour. The study data included the manuscripts edited by the students.

\subsection{Data analysis}

The texts edited by the students were collected and examined and the punctuation marks in the edited texts were compared with the original text. The different uses of punctuation marks were classified as correct and incorrect by the author, who is a linguist, to obtain the raw study data.

Two different types of mistakes were identified in student texts. One type of error was the use of incorrect punctuation mark, and the other was to use a punctuation mark where there is no need, and to use no punctuation where there should be a punctuation mark. Thus, the texts were examined with two approaches. The first approach included the number of general correct/incorrect punctuation mark use in the whole text and the second included the correct/ incorrect use of the punctuation marks at each point in the text.

The analysis of the raw data collected in the study was conducted with IBM SPSS Statistics 22 software. Data analysis was conducted with independent samples t-test, one-way analysis of variance (ANOVA) and post hoc tests. In the tables presented in this paper, sample size is indicated by $\mathrm{N}$, arithmetic mean is indicated by $\overline{\mathrm{x}}$, standard deviation is indicated by $\mathrm{S}$, and the degree of freedom is indicated by df. The variance equation for the groups was determined with the Levene's test and differences between the groups were interpreted at 0.05 significance level.

H0: There is no significant difference between the correct use of punctuation marks based on gender.

$\mathrm{H} 1$ : There is significant difference between the correct use of punctuation marks based on gender.

In order to determine whether the student data differed significantly based on student department, the mean counts for double period, dash, period, semicolon, question mark, quotation mark, exclamation point and comma punctuation marks were tested with one-way ANOVA. In this test, the punctuation marks were not analyzed based on each use in the text, but based on total number of correct/incorrect use throughout the text. Then, the mistakes made by the students based on each point of use were analyzed. In the tables, sample size is indicated by $\mathrm{N}$, arithmetic mean is indicated by $\overline{\mathrm{x}}$, standard deviation is indicated by $\mathrm{S}$. The variance equation for the groups was determined with the Levene's test and differences between the groups were interpreted at 0.05 significance level.

H0: There is no significant difference between the correct use of punctuation marks based on student department. 
H1: There is significant difference between the correct use of punctuation marks based on student department.

Independent samples t-test was used to determine whether the use of punctuation marks differed based on gender. In this section, punctuation marks were analyzed based on total correct use in the manuscript, not based on the point they were used in the sentence.

\section{Results}

In this section, findings on the number of correct/incorrect uses of the punctuation marks based on the points where the punctuation marks were used by the students in the text, gender and student department are presented. The findings were as follows:

\subsection{Period (.)}

In the original manuscript, the period mark was used at the end of 12 sentences (Yazım Kilavuzu, 2012, p. 27). The function of period is the same at each point of use. The difficulty rate could be different for each student.

The rates of total correct/incorrect use for the period are presented in Table 2:

Table 2. The rates of total correct/incorrect use for the period

\begin{tabular}{ccccccc}
\hline & $\begin{array}{c}\text { Turkish } \\
\text { Language } \\
(\%)\end{array}$ & $\begin{array}{c}\text { PCG I. 1/A } \\
(\%)\end{array}$ & $\begin{array}{c}\text { PCG I. 1/B } \\
(\%)\end{array}$ & $\begin{array}{c}\text { PCG II. 1/A } \\
(\%)\end{array}$ & $\begin{array}{c}\text { PCG II. 1/B } \\
(\%)\end{array}$ & $\begin{array}{c}\text { Total } \\
(\%)\end{array}$ \\
\hline Correct & 68.95 & 62.40 & 65.56 & 65.52 & 66.93 & 65.87 \\
Incorrect & 31.05 & 37.6 & 34.44 & 34.48 & 33.07 & 34.13 \\
\hline
\end{tabular}

Based on the study data, the correct use of point mark by all students was 65,87 . Two thirds of the students used the period mark correctly. However, this accuracy rate was insufficient for the period mark, which is one of the most basic and important marks.

For a more detailed analysis of the mistakes made when using the period mark, the data collected for each point of use were processed and the findings are presented in the following tables in the form of correct and incorrect usage data:

Table 3. Correct use of the period mark at each point of use

\begin{tabular}{ccccccc}
\hline Correct & $\begin{array}{c}\text { Turkish } \\
\text { Language } \\
(\%)\end{array}$ & $\begin{array}{c}\text { PCG I. 1/A } \\
(\%)\end{array}$ & $\begin{array}{c}\text { PCG I. 1/B } \\
(\%)\end{array}$ & $\begin{array}{c}\text { PCG II. 1/A } \\
(\%)\end{array}$ & $\begin{array}{c}\text { PCG II. 1/B } \\
(\%)\end{array}$ & Total (\%) \\
\hline 1. & 54.65 & 28.65 & 29.45 & 38.75 & 32.5 & 36.80 \\
2. & 45.35 & 37.45 & 44.65 & 57.15 & 56.55 & 48.23 \\
3. & 84.75 & 86.4 & 98.2 & 87.1 & 95.3 & 90.35 \\
4. & 69.0 & 55.9 & 76.8 & 69.2 & 70.3 & 68.24
\end{tabular}




$\begin{array}{ccccccc}5 . & 80.1 & 88.8 & 82.15 & 92.3 & 86.3 & 85.93 \\ 6 . & 90.3 & 94.1 & 96.45 & 87.1 & 85.3 & 90.65 \\ 7 . & 79.2 & 59.25 & 64.3 & 74.15 & 70.6 & 69.50 \\ 8 . & 25.9 & 18.9 & 15.2 & 3.55 & 10.95 & 14.90 \\ 9 . & 81.95 & 79.95 & 83.05 & 78.0 & 81.9 & 80.97 \\ 10 . & 88.45 & 94.1 & 96.45 & 98.1 & 98.45 & 95.11 \\ 11 . & 33.8 & 6.8 & 3.55 & 11.55 & 18.15 & 14.77 \\ 12 . & 94.0 & 98.55 & 96.45 & 89.3 & 96.9 & 95.04\end{array}$

Table 4. Incorrect use of the period mark based on each point it was used in the sentence

\begin{tabular}{ccccccc}
\hline Incorrect & $\begin{array}{c}\text { Turkish } \\
\text { Language } \\
(\%)\end{array}$ & $\begin{array}{c}\text { PCG I. 1/A } \\
(\%)\end{array}$ & $\begin{array}{c}\text { PCG I. 1/B } \\
(\%)\end{array}$ & $\begin{array}{c}\text { PCG II. 1/A } \\
(\%)\end{array}$ & $\begin{array}{c}\text { PCG II. 1/B } \\
(\%)\end{array}$ & Total (\%) \\
\hline 1. & 45.35 & 71.35 & 70.55 & 61.25 & 67.5 & 63.20 \\
2. & 54.65 & 62.55 & 55.35 & 42.85 & 43.45 & 51.77 \\
3. & 15.25 & 13.6 & 1.8 & 12.9 & 4.7 & 9.65 \\
4. & 31.0 & 44.1 & 23.2 & 30.8 & 29.7 & 31.76 \\
5. & 19.9 & 11.2 & 17.85 & 7.7 & 14.7 & 14.27 \\
6. & 9.7 & 5.9 & 3.55 & 12.9 & 14.7 & 9.35 \\
7. & 20.8 & 40.75 & 35.7 & 25.85 & 29.4 & 30.50 \\
8. & 74.1 & 81.1 & 84.8 & 96.45 & 89.05 & 85.10 \\
9. & 18.05 & 20.05 & 16.95 & 22.0 & 18.15 & 19.04 \\
10. & 11.55 & 5.9 & 3.55 & 1.9 & 1.55 & 4.89 \\
11. & 66.2 & 93.2 & 96.45 & 88.45 & 81.9 & 85.24 \\
12. & 6.0 & 1.45 & 3.55 & 10.7 & 3.15 & 4.97 \\
\hline
\end{tabular}

Review of the table demonstrated that the correct/incorrect use of the period mark by the students was different on each point of use. The number of incorrect uses was higher than the number of correct uses at points 1, 2, 8 and 11 in the text. The students used the period mark mostly correctly $(95.11 \%)$ on the 10th point of use and made the highest number of mistakes (85.24\%) on the 11th point of use. It was determined that certain students used more than 12 period marks since they preferred the period instead of a comma in order to separate ordered sentences.

The rate of correct use of the period where it should be first used was $36.80 \%$ and incorrect use rate was $63.20 \%$. This was due to the fact that the students made a mistake when determining the last word in a sentence.

The rate of correct use of the period where it should be used secondly was $48.23 \%$ and incorrect use rate was $51.77 \%$. The students used the period incorrectly since they confused the subject of the first sentence and that of the following sentence. 
At the 8th point of the manuscript, students used the period sign incorrectly because they could not form a correct sentence.

In period use, the students made the highest number of mistakes on the 11th point in the manuscript. This difficulty was due to the fact that the text was an excerpt from a work of art. In didactic texts, a sentence would not start with an "and." However, in the text, the next sentence starts with an "and," thus confusing the students about the beginning of the next sentence and used a comma instead of a period.

However, at point 12, there were students who did not use a period at the end of the last sentence of the manuscript, although there was nothing to confuse the students.

Findings related to the sub-problem of whether there was a difference between the use of period marks in the text that the students edited based on the student department are presented below:

Table 5. One-Way ANOVA Comparison of Correct Period Use Based on the Department Variable

\begin{tabular}{cccccc}
\hline Group & $\mathrm{N}$ & $\overline{\mathrm{x}}$ & $\mathrm{S}$ & $\mathrm{F}$ & $\mathrm{p}$ \\
\hline Turkish Language & 39 & 8.1538 & 2.56021 & & \\
PCG I. 1/A & 47 & 7.1915 & 1.65027 & & \\
PCG I. 1/B & 36 & 7.6667 & 1.77281 & & \\
PCG II. 1/A & 40 & 7.7000 & 1.39963 & & .177 \\
PCG II. 1/B & 42 & 7.8810 & 1.65577 & & \\
Total & 204 & 7.7010 & 1.84999 & & \\
\hline
\end{tabular}

As seen in the table, the distribution that represents the One-Way ANOVA test conducted to determine the correct /incorrect period mark use of the students based on the department variable demonstrated that there was no significant difference between the students' correct use of the period mark based on the student department variable $\left(\mathrm{F}(4,199)=1.596 ; \mathrm{p}=.177\right.$. If $\mathrm{p}>0.05$ then $\mathrm{H}_{0}$ is accepted) (Variances were not equal based on the Levene's test.)

The results of the t-test conducted to determine the difference between correct and incorrect use of the period mark are presented below:

Table 6. Comparison of the use of period based on gender

\begin{tabular}{ccccccc}
\hline Group & $\mathrm{N}$ & $\overline{\mathrm{x}}$ & $\mathrm{S}$ & $\mathrm{t}$ & $\mathrm{df}$ & $\mathrm{p}$ \\
\hline Female & 147 & 7.6531 & 1.80810 & \multirow{2}{*}{-.593} & 202 & .554 \\
Male & 57 & 7.8246 & 1.96508 & & & \\
\hline
\end{tabular}

As in the table, the both group mean values were similar. There was no statistically significant difference between the total number of correct use of the period mark based on gender $(\mathrm{t}(202)=-.593$; $\mathrm{p}=.554$, If $\mathrm{p}>0.05$ then $\mathrm{H}_{0}$ is accepted).

\subsection{Comma (,)}

The comma mark was used in 18 points in the original manuscript. The functions of this mark include separating ordered sentences, used at the end of a quoted sentence, after the words with adverb or verb 
suffix, to identify the subject located away from predicate in long sentences, and between words or word groups with similar functions (Yazim Kilavuzu, 2012).

The total correct/incorrect comma use rates are presented below:

Table 7. The total correct/incorrect comma use rates

\begin{tabular}{ccccccc}
\hline $\begin{array}{c}\text { Correct / } \\
\text { Incorrect }\end{array}$ & $\begin{array}{c}\text { Turkish } \\
\text { Language } \\
(\%)\end{array}$ & $\begin{array}{c}\text { PCG I. 1/A } \\
(\%)\end{array}$ & $\begin{array}{c}\text { PCG I. 1/B } \\
(\%)\end{array}$ & $\begin{array}{c}\text { PCG II. 1/A } \\
(\%)\end{array}$ & $\begin{array}{c}\text { PCG II. 1/B } \\
(\%)\end{array}$ & $\begin{array}{c}\text { Total } \\
(\%)\end{array}$ \\
\hline Correct & 16,44 & 10,87 & 14,93 & 13,96 & 13,53 & 13,95 \\
Incorrect & 83,56 & 89,13 & 85,07 & 86,04 & 86,47 & 86,05 \\
\hline
\end{tabular}

Review of the findings on the use of comma mark demonstrated that the incorrect use rate was very high (86.05\%).

It was considered that it would beneficial to review the statistical data on each point of use of the comma in order to obtain better results on the use of comma. A detailed review of the comma use is presented in the following tables.

Table 8. Correct use of comma based on each point of use

\begin{tabular}{ccccccc}
\hline Correct & $\begin{array}{c}\text { Turkish } \\
\text { Language } \\
(\%)\end{array}$ & $\begin{array}{c}\text { PCG I. 1/A } \\
(\%)\end{array}$ & $\begin{array}{c}\text { PCG I. 1/B } \\
(\%)\end{array}$ & $\begin{array}{c}\text { PCG II. 1/A } \\
(\%)\end{array}$ & $\begin{array}{c}\text { PCG II. 1/B } \\
(\%)\end{array}$ & $\begin{array}{c}\text { Total } \\
(\%)\end{array}$ \\
\hline 1. & 15.25 & 1.45 & 5.35 & 0 & 1.55 & 4.72 \\
2. & 11.55 & 18.9 & 8.95 & 13.15 & 12.8 & 13.07 \\
3. & 10.2 & 8.25 & 12.5 & 3.85 & 20.95 & 11.15 \\
4. & 18.7 & 8.25 & 8.05 & 7.7 & 13.15 & 11.17 \\
5. & 31.0 & 24.2 & 50.9 & 40.7 & 36.9 & 36.74 \\
6. & 6.0 & 6.8 & 1.8 & 3.55 & 8.15 & 5.26 \\
7. & 16.2 & 12.1 & 13.4 & 11.25 & 7.8 & 12.15 \\
8. & 0 & 1.45 & 9.8 & 3.85 & 1.55 & 3.33 \\
9. & 10.2 & 1.45 & 3.55 & 9.6 & 1.55 & 5.27 \\
10. & 6.0 & 4.4 & 3.55 & 7.7 & 3.15 & 4.96 \\
11. & 9.7 & 9.75 & 13.4 & 17.0 & 11.25 & 12.22 \\
12. & 23.6 & 12.65 & 24.1 & 26.4 & 27.8 & 22.91 \\
13. & 62.5 & 49.2 & 71.45 & 58.0 & 50.0 & 58.23 \\
14. & 16.65 & 12.1 & 15.2 & 18.4 & 11.25 & 14.72 \\
15. & 37.95 & 9.75 & 7.15 & 11.25 & 14.7 & 16.16 \\
16. & 8.35 & 2.95 & 0 & 5.75 & 6.55 & 4.72 \\
17. & 4.15 & 1.45 & 0 & 0 & 0 & 1.12 \\
18. & 7.85 & 10.65 & 19.65 & 13.15 & 14.4 & 13.14 \\
\hline & & & & & & \\
\hline
\end{tabular}


Table 9. Incorrect use of comma based on each point of use

\begin{tabular}{ccccccc}
\hline Incorrect & $\begin{array}{c}\text { Turkish } \\
\text { Language } \\
(\%)\end{array}$ & $\begin{array}{c}\text { PCG I. 1/A } \\
(\%)\end{array}$ & $\begin{array}{c}\text { PCG I. 1/B } \\
(\%)\end{array}$ & $\begin{array}{c}\text { PCG II. 1/A } \\
(\%)\end{array}$ & $\begin{array}{c}\text { PCG II. 1/B } \\
(\%)\end{array}$ & $\begin{array}{c}\text { Total } \\
(\%)\end{array}$ \\
\hline 1. & 84.75 & 98.55 & 94.65 & 100.0 & 98.45 & 95.28 \\
2. & 88.45 & 81.1 & 91.05 & 86.85 & 87.2 & 86.93 \\
3. & 89.8 & 91.75 & 87.5 & 96.15 & 79.05 & 88.85 \\
4. & 87.95 & 91.75 & 91.95 & 92.3 & 86.85 & 90.16 \\
5. & 69.0 & 75.8 & 49.1 & 59.3 & 63.15 & 63.27 \\
6. & 94.0 & 93.2 & 98.2 & 96.45 & 91.9 & 94.75 \\
7. & 83.8 & 87.9 & 86.6 & 88.75 & 92.2 & 87.85 \\
8. & 100.0 & 98.55 & 90.2 & 96.15 & 98.45 & 96.67 \\
9. & 89.8 & 98.55 & 96.45 & 90.4 & 98.45 & 94.73 \\
10. & 94.0 & 95.6 & 96.45 & 92.3 & 96.9 & 95.05 \\
11. & 90.3 & 90.25 & 86.6 & 83.0 & 88.75 & 87.78 \\
12. & 76.4 & 87.35 & 75.9 & 73.6 & 72.2 & 77.09 \\
13. & 37.5 & 50.8 & 28.55 & 42.0 & 50.0 & 41.77 \\
14. & 83.35 & 87.9 & 84.8 & 81.6 & 88.75 & 85.28 \\
15. & 62.05 & 90.25 & 92.85 & 88.75 & 85.3 & 83.84 \\
16. & 91.65 & 97.05 & 100.0 & 94.25 & 93.45 & 95.28 \\
17. & 95.85 & 98.55 & 100.0 & 100.0 & 100.0 & 98.88 \\
18. & 92.15 & 89.35 & 80.35 & 86.85 & 85.65 & 86.87 \\
\hline
\end{tabular}

Review of the above tables demonstrated that the incorrect use of comma at point 13 was higher than correct use with $58.23 \%$. It was determined that none of the students in certain departments did not use the comma accurately in $1^{\text {st }}$ and $17^{\text {th }}$ points. This demonstrated that certain students did not know certain functions of the comma.

Review of the texts edited by the students demonstrated that they generally preferred to use commas when editing the text; however, they were not able to use it in the right places. Most of the students made the mistake of using a comma where they should use a period and using a period where they should use a comma. This demonstrated that students did not have the knowledge on the functions of the comma and the skills to use comma at adequate points in a sentence.

Review of the texts demonstrated that the students used periods where they should have used commas. Instead of separating ordered sentences with commas, they chose to end the first sentence with a period. There were students who did not use a comma among the elements used for the same function in the sentence. This demonstrated that students had problems in sentence knowledge.

Findings on the sub-problem of whether there was a difference between comma use in the manuscripts that the students edited based on the departments are presented below: 
Table 10. One-Way ANOVA Comparison of Correct Comma Use Based on the Department Variable

\begin{tabular}{cccccc}
\hline Group & $\mathrm{N}$ & $\overline{\mathrm{x}}$ & $\mathrm{S}$ & $\mathrm{F}$ & $\mathrm{p}$ \\
\hline Turkish language & 39 & 2.8205 & 2.02448 & & \\
PCG I. 1/A & 47 & 2.0426 & 1.79319 & & \\
PCG I. 1/B & 36 & 2.7222 & 2.00871 & & \\
PCG II. 1/A & 40 & 2.7750 & 2.32586 & & .392 \\
PCG II. 1/B & 42 & 2.4524 & 2.38084 & & \\
Total & 204 & 2.5392 & 2.11339 & & \\
\hline
\end{tabular}

As seen in the table that demonstrated the comparison of the One-Way ANOVA findings on the correct/incorrect use of comma by the students based on the department variable, there was no significant difference between correct comma use rates of the students based on the department variable $\left(\mathrm{F}(4,199)=1.032 ; \mathrm{p}=, 392\right.$ If $\mathrm{p}>0.05$ then $\mathrm{H}_{0}$ is accepted. Variances were equal based on the Levene's test.)

Based on the Levene's test conducted to determine whether the correct comma use differed based on gender, the variances of the two groups were equal and the results of the t-test are presented below:

Table 11. Comparison of the comma use based on gender

\begin{tabular}{ccccccc}
\hline Group & $\mathrm{N}$ & $\overline{\mathrm{x}}$ & $\mathrm{S}$ & $\mathrm{t}$ & $\mathrm{df}$ & $\mathrm{p}$ \\
\hline Female & 147 & 2.6531 & 2.10236 & \multirow{2}{*}{1.237} & 202 & .217 \\
Male & 57 & 2.2456 & 2.13207 & & &
\end{tabular}

As seen in the table, based on the results of the t-test, it was observed that there was no statistically significant difference between the total number of correct comma use based on student gender $(\mathrm{t}(202)$ $=1,237 ; \mathrm{p}=, 217$, if $\mathrm{p}>0.05$ then $\mathrm{H}_{0}$ is accepted.) . The mean figures for both groups were similar.

\subsection{Question Mark (?)}

In the original text, the question mark was used only in one point at the end of a sentence that includes a question (Yazım Kilavuzu, 2012, p. 33). The total correct/incorrect question mark use rates are presented below:

Table 12. The total correct/incorrect question mark use rates

\begin{tabular}{ccccccc}
\hline & $\begin{array}{c}\text { Turkish } \\
\text { language }(\%)\end{array}$ & $\begin{array}{c}\text { PCG I. 1/A } \\
(\%)\end{array}$ & $\begin{array}{c}\text { PCG I. 1/B } \\
(\%)\end{array}$ & $\begin{array}{c}\text { PCG II. 1/A } \\
(\%)\end{array}$ & $\begin{array}{c}\text { PCG II. 1/B } \\
(\%)\end{array}$ & $\begin{array}{c}\text { Total } \\
(\%)\end{array}$ \\
\hline Correct & 87.95 & 85.85 & 83.95 & 88.75 & 80.95 & 85.49 \\
Incorrect & 12.05 & 14.15 & 16.05 & 11.25 & 19.05 & 14.51 \\
\hline
\end{tabular}


Review of the question mark use of the students demonstrated that the correct use rate was higher than the incorrect use rate. This is the second punctuation mark where the correct use was the second highest following the period use. The question mark is one of the first punctuation marks instructed in the initial literacy training. Correct use of the question mark was lower than expected. The reasons for this may include the fact that the students did not know that a question mark should be placed at the end of a question or the students could not comprehend the prose manuscript provided.

Findings on the sub-problem of whether there was a difference between question mark use based on the student department in the manuscripts that the students edited are presented below:

Table 13. One-Way ANOVA Comparison of Correct Question Mark Use Based on the Department Variable

\begin{tabular}{cccccc}
\hline Group & $\mathrm{N}$ & $\overline{\mathrm{x}}$ & $\mathrm{S}$ & $\mathrm{F}$ & $\mathrm{p}$ \\
\hline Turkish language & 39 & .8974 & .30735 & & \\
PCG I. 1/A & 47 & .8298 & .37988 & & \\
PCG I. 1/B & 36 & .8889 & .31873 & & \\
PCG II. 1/A & 40 & .8750 & .33493 & .987 & .416 \\
PCG II. 1/B & 42 & .7619 & .43108 & \\
Total & 204 & .8480 & .35987 & & \\
\hline
\end{tabular}

In the distribution that presents the comparison of the One-Way ANOVA test on the level of correct/incorrect question mark use based on the student department variable, it was observed that there was no significant difference between the correct question mark use based on student department variable $\left(\mathrm{F}(4,199)=.987 ; \mathrm{p}=.416\right.$ If $\mathrm{p}>0.05$, then $\mathrm{H}_{0}$ is accepted. Variances were not equal based on the Levene's test).

Analysis findings on the correct question mark use based on gender variable are presented below. Based on the Levene's test, the variances of the two groups were equal and the results of the t-test are presented below:

Table 14. Comparison of the question mark use based on gender

\begin{tabular}{lllllll}
\hline & $\mathrm{N}$ & $\overline{\mathrm{x}}$ & $\mathrm{S}$ & $\mathrm{t}$ & $\mathrm{df}$ & $\mathrm{p}$ \\
\hline Female & 147 & .8367 & .37087 & & & \\
Male & 57 & .8772 & .33113 & -.720 & 202 & .473 \\
\hline
\end{tabular}

There was no statistically significant difference between the total correct question mark use between female and male students based on the t-test results conducted to compare the question mark use based on gender $\left(\mathrm{t}(202)=-, 720 ; \mathrm{p}=, 473\right.$, if $\mathrm{p}>0.05$ then $\mathrm{H}_{0}$ is accepted). The mean figures for both groups were similar and there was no difference between the question mark use based on gender.

\subsection{Exclamation point (!)}

The exclamation point is used in two points in the original manuscripts at the end of sentences or phrases that expressed feelings such as joy, pain, fear and astonishment and after words of calling, 
address and warning (Yazım Kılavuzu, 2012). The correct/incorrect use rate for exclamation point are presented in the table below:

Table 15. The total correct/incorrect exclamation point use rates

\begin{tabular}{ccccccc}
\hline $\begin{array}{c}\text { Correct / } \\
\text { Incorrect }\end{array}$ & $\begin{array}{c}\text { Turkish } \\
\text { Language } \\
(\%)\end{array}$ & $\begin{array}{c}\text { PCG I. 1/A } \\
(\%)\end{array}$ & $\begin{array}{c}\text { PCG I. 1/B } \\
(\%)\end{array}$ & $\begin{array}{c}\text { PCG II. } \\
1 / \mathrm{A}(\%)\end{array}$ & $\begin{array}{c}\text { PCG II. 1/B } \\
(\%)\end{array}$ & $\begin{array}{c}\text { Total } \\
(\%)\end{array}$ \\
\hline Correct & 18.75 & 25.08 & 28.13 & 20.48 & 18.75 & 22.24 \\
Incorrect & 81.25 & 74.92 & 71.87 & 79.52 & 81.25 & 77.76 \\
\hline
\end{tabular}

Review of the data presented in the table demonstrated that the student mistakes were $77.76 \%$ of the total exclamation point use in the text they edited. The exclamation point, which is used to reflect an astonishment and calling was used for its most common functions in the text. Review of the incorrect exclamation point use demonstrated that the students confused the exclamation point with the question mark and used a question mark or a period instead of the exclamation point. This demonstrated that the students did not fully comprehend the emotions that require an exclamation such as pain, confusion, joy and anger in the manuscript. In other words, it can be suggested that students experienced reading comprehension and interpretation problems.

Findings on the sub-problem of whether there was a difference between exclamation point use based on the student department in the manuscripts that the students edited are presented below:

Table 16. One-Way ANOVA Comparison of Correct Exclamation Point Use Based on the Department Variable

\begin{tabular}{cccccc}
\hline Group & $\mathrm{N}$ & $\overline{\mathrm{x}}$ & $\mathrm{S}$ & $\mathrm{F}$ & $\mathrm{p}$ \\
\hline Turkish language & 39 & .3590 & .53740 & & \\
PCG I. 1/A & 47 & .5532 & .61885 & & \\
PCG I. 1/B & 36 & .6667 & .58554 & & \\
PCG II. 1/A & 40 & .4250 & .59431 & 2.626 & .036 \\
PCG II. 1/B & 42 & .3095 & .46790 & & \\
Total & 204 & .4608 & .57315 & & \\
\hline
\end{tabular}

In the distribution that presents the comparison of the One-Way ANOVA test on the level of correct/incorrect exclamation point use based on the student department variable, it was observed that there was a significant difference between the correct exclamation point use based on student department variable $\left(\mathrm{F}(4,199)=2.626 ; \mathrm{p}=.036\right.$ If $\mathrm{p}<0.05$, then $\mathrm{H}_{0}$ is rejected. Variances were equal based on the Levene's test). Based on the One-Way ANOVA test results, at least one of the groups was different. In order to determine which group was different, Tukey HSD test, a Post Hoc test, was conducted. The test results are presented below: 
Table 17. The Results of the Tukey HSD Test Conducted to Determine the Different Department

\begin{tabular}{ccccc}
\hline (I) department & (J) department & $\begin{array}{c}\text { The difference between } \\
\text { the means (I-J) }\end{array}$ & Std. Error & $\mathrm{p}$ \\
\hline PCG 1.1/B & $\begin{array}{c}\text { Turkish } \\
\text { language }\end{array}$ & .30769 & .13040 & .131 \\
& PCG I. 1/A & .11348 & .12496 & .894 \\
& PCG II. 1/B & $.35714^{*}$ &. $\mathbf{1 2 8 1 4}$ & $\mathbf{. 0 4 6}$ \\
& PCG II. 1/A & .24167 & .12961 & .340 \\
\hline
\end{tabular}

As seen in the table, there was a significant difference between correct exclamation point use rats of PDR I. 1-B and PDR II. 1-B departments (classes). In other words, the mean correct exclamation point use level of the PDR I. 1-B class was higher when compared to other classes.

The data obtained with the analysis of exclamation point use by gender were as follows. Based on the Levene test, the variances of the two groups were equal and t-test results are presented in the table below:

Table 18. Comparison of the exclamation point use based on gender

\begin{tabular}{ccccccc}
\hline Group & $\mathrm{N}$ & $\overline{\mathrm{x}}$ & $\mathrm{S}$ & $\mathrm{t}$ & $\mathrm{df}$ & $\mathrm{p}$ \\
\hline Female & 147 & .4830 & .58933 & .888 & 202 & .375 \\
Male & 57 & .4035 & .52981 & & & \\
\hline
\end{tabular}

There was no statistically significant difference between male and female students in the t-test conducted to compare the total number of correct exclamation point use by gender (t 202) =, 888; $\mathrm{p}=$, 375 , if $\mathrm{p}>0.05$ then $\mathrm{H}_{0}$ was accepted). The averages of both groups were similar and there was no difference based on gender.

\subsection{Quotation Marks (“”)}

The quotation marks were used in the original text in 3 points to emphasize certain quotations and to replace the das used before quotations (Yazım Kilavuzu, 2012). During the review of student manuscripts, use of dash or quotation marks were considered correct and use of both marks was considered incorrect. The table that includes the data collected from the students on the use of quotation marks is presented below:

Table 19. The total correct/incorrect quotation mark use

\begin{tabular}{ccccccc}
\hline $\begin{array}{c}\text { Correct / } \\
\text { Incorrect }\end{array}$ & $\begin{array}{c}\text { Turkish } \\
\text { Language } \\
(\%)\end{array}$ & $\begin{array}{c}\text { PCG I. 1/A } \\
(\%)\end{array}$ & $\begin{array}{c}\text { PCG I. 1/B } \\
(\%)\end{array}$ & $\begin{array}{c}\text { PCG II. 1/A } \\
(\%)\end{array}$ & $\begin{array}{c}\text { PCG II. 1/B } \\
(\%)\end{array}$ & $\begin{array}{c}\text { Total } \\
(\%)\end{array}$ \\
\hline Correct & 34.25 & 23.88 & 27.97 & 28.95 & 26.87 & 28.38 \\
Incorrect & 65.75 & 76.12 & 72.03 & 71.05 & 73.13 & 71.62 \\
\hline
\end{tabular}


As seen in the table, the incorrect quotation mark use was higher than the correct quotation mark use. The students either used the quotation marks and dash together or they did not use any marks at all. This demonstrated that the students did not have sufficient knowledge about the rule that quotation marks should be used to emphasize the quotes and could not be used with dash. Correct usage was higher in the text where there were clue words such as "he said," and "she added" that indicated the use of quotation marks.

Findings on the sub-problem of whether there was a difference between quotation mark use based on the student department in the manuscripts that the students edited are presented below:

Table 20. One-Way ANOVA Comparison of Correct Quotation Mark Use Based on the Department Variable

\begin{tabular}{cccccc}
\hline Group & $\mathrm{N}$ & $\overline{\mathrm{x}}$ & $\mathrm{S}$ & $\mathrm{F}$ & $\mathrm{p}$ \\
\hline Turkish language & 39 & 1.1026 & 1.02070 & & \\
PCG I. 1/A & 47 & .8298 & .84233 & & \\
PCG I. 1/B & 36 & 1.0278 & .87786 & & \\
PCG II. 1/A & 40 & .8500 & .76962 & .978 & .421 \\
PCG II. 1/B & 42 & .8095 & .70670 & & \\
Total & 204 & .9167 & .84685 & & \\
\hline
\end{tabular}

As seen in the table, the distribution of the One-Way ANOVA test on the level of correct / incorrect use of quotation marks by the students based on the student department variable revealed no significant difference between the correct quotation mark use of the students based on student department $(\mathrm{F}(4,199)$ $=, 978 ; \mathrm{p}=, 421$, if $\mathrm{p}>0.05$ then $\mathrm{H}_{0}$ is accepted. Variances were equal based on the Levene's test).

The data obtained with the analysis of quotation mark use by gender were as follows. Based on the Levene test, the variances of the two groups were equal and t-test results are presented in the table below:

Table 21. Comparison of quotation mark use based on gender

\begin{tabular}{ccccccc}
\hline Group & $\mathrm{N}$ & $\overline{\mathrm{x}}$ & $\mathrm{S}$ & $\mathrm{t}$ & $\mathrm{df}$ & $\mathrm{p}$ \\
\hline Female & 147 & .9932 & .85605 & 2.090 & 202 & .038 \\
Male & 57 & .7193 & .79629 & & &
\end{tabular}

A statistically significant difference was determined between the total number of correct quotation mark use of female and male students based on t-test results conducted to compare quotation mark use based on gender ( $\mathrm{t}(202)=2,090 ; \mathrm{p}=, 038$, if $\mathrm{p}<0,05$ then $\mathrm{H}_{0}$ is rejected). The rate of incorrect use was higher than the correct use rate for both genders. However, when the group averages were reviewed, it was observed that mean rate for females was .9932 , while the same was .7193 for male students. In other words, female students used the quotation mark more correctly when compared to male students. As the number of use increased in both genders, the percentage of correct use decreased. 


\subsection{Colon (:)}

Colon was used in 5 points in the original manuscript. In the following table, the correct/incorrect colon use in the texts that the students edited is presented:

Table 22. The total correct/incorrect colon use

\begin{tabular}{ccccccc}
\hline Correct / & $\begin{array}{c}\text { Turkish } \\
\text { Incorrect }\end{array}$ & $\begin{array}{c}\text { PCG I. 1/A } \\
(\%)\end{array}$ & $\begin{array}{c}\text { PCG I. 1/B } \\
(\%)\end{array}$ & $\begin{array}{c}\text { PCG II. 1/A } \\
(\%)\end{array}$ & $\begin{array}{c}\text { PCG II. 1/B } \\
(\%)\end{array}$ & $\begin{array}{c}\text { Total } \\
(\%)\end{array}$ \\
\hline Correct & 24.25 & 20.19 & 20.91 & 22.29 & 22.31 & 21.99 \\
Incorrect & 75.75 & 79.81 & 79.09 & 77.71 & 77.69 & 78.01 \\
\hline
\end{tabular}

The data presented in the table demonstrated that incorrect colon use rate by the students was $78.01 \%$. The findings demonstrated that the majority of students did not have adequate knowledge about colon use. Furthermore, it was found that the colons were not used adequately by any student and the number of the students who never used the colon in the text was higher than the students who used the colon. $30.6 \%$ of female and $40.4 \%$ of male students used colon. As the number of use increased, the percentage of correct use decreased.

Whether the colon use differed by gender is presented in the table below. Based on the Levene's test, the variances of the two groups were equal. The results of the t-test are presented below:

Table 23. Comparison of colon use based on gender

\begin{tabular}{ccccccc}
\hline Group & $\mathrm{N}$ & $\overline{\mathrm{x}}$ & $\mathrm{S}$ & $\mathrm{t}$ & $\mathrm{df}$ & $\mathrm{p}$ \\
\hline Female & 147 & 1.1701 & .98880 & .859 & 202 & .391 \\
Male & 57 & 1.0351 & 1.05161 & & & \\
\hline
\end{tabular}

Findings on the sub-problem of whether there was a difference between colon uses based on the student department in the manuscripts that the students edited are presented below:

Table 24. One-Way ANOVA Comparison of Correct Colon Use Based on the Department Variable

\begin{tabular}{cccccc}
\hline Group & $\mathrm{N}$ & $\overline{\mathrm{x}}$ & $\mathrm{S}$ & $\mathrm{F}$ & $\mathrm{p}$ \\
\hline Turkish language & 39 & 1.2308 & .95866 & & \\
PCG I. 1/A & 47 & .9787 & 1.01058 & & \\
PCG I. 1/B & 36 & 1.2778 & 1.00317 & & \\
PCG II. 1/A & 40 & 1.1500 & 1.05125 & .592 & .669 \\
PCG II. 1/B & 42 & 1.0714 & 1.02154 & & \\
Total & 204 & 1.1324 & 1.00596 & & \\
\hline
\end{tabular}


As seen in the table, the distribution of the One-Way ANOVA test on the level of correct / incorrect use of colon by the students based on the student department variable revealed no significant difference between the correct colon use based on student department $\left(F(4,199)=.592 ; \mathrm{p}=.669\right.$, if $\mathrm{p}>0.05$ then $\mathrm{H}_{0}$ is accepted. Variances were equal based on the Levene's test).

No statistically significant difference was determined between the total number of correct colon use by female and male students based on t-test results conducted to compare colon use based on gender $\left(\mathrm{t}(202)=.859 ; \mathrm{p}=.391\right.$, if $\mathrm{p}>0.05$ then $\mathrm{H}_{0}$ is accepted). In other words, there was no difference between the genders based on correct colon use.

\subsection{Semicolon (;)}

The semicolon is used at one point in the original manuscript to separate ordered sentences that included commas between their elements (Yazım Kilavuzu, 2012, p. 31). The statistical data on the correct/incorrect semicolon use by the students in the edited manuscript are presented in the table below:

Table 25. The total correct/incorrect semicolon use

\begin{tabular}{ccccccc}
\hline $\begin{array}{c}\text { correct / } \\
\text { incorrect }\end{array}$ & $\begin{array}{c}\text { Turkish } \\
\text { Language } \\
(\%)\end{array}$ & $\begin{array}{c}\text { PCG I. 1/A } \\
(\%)\end{array}$ & $\begin{array}{c}\text { PCG I. 1/B } \\
(\%)\end{array}$ & $\begin{array}{c}\text { PCG II. 1/A } \\
(\%)\end{array}$ & $\begin{array}{c}\text { PCG II. 1/B } \\
(\%)\end{array}$ & $\begin{array}{c}\text { Total } \\
(\%)\end{array}$ \\
\hline Correct & 0 & 2.95 & 0 & 5.45 & 3.2 & 2.32 \\
Incorrect & 100.0 & 97.05 & 100.0 & 94.55 & 96.9 & 97.70 \\
\hline
\end{tabular}

It was observed that almost no student was able to demonstrate the correct skill. For both genders, the rate of incorrect use was higher than correct use. Semicolon was used in the text edited by the students, however it was used in incorrect points in the sentences. In general, students used a semicolon where a colon should be used. In other words, the students confused the semicolon with the colon. This demonstrated that the students had problems in acquisition of the knowledge on semicolon.

Findings on the sub-problem of whether there was a difference between semicolon uses based on the student department in the manuscripts that the students edited are presented below:

Table 26. One-Way ANOVA Comparison of Correct Semicolon Use Based on the Department Variable

\begin{tabular}{cccccc}
\hline Group & $\mathrm{N}$ & $\overline{\mathrm{x}}$ & $\mathrm{S}$ & $\mathrm{F}$ & $\mathrm{p}$ \\
\hline Turkish language & 39 & .0000 & .00000 & & \\
PCG I. 1/A & 47 & .0426 & .20403 & & \\
PCG I. 1/B & 36 & .0000 & .00000 & & \\
PCG II. 1/A & 40 & 0.500 & .22072 & .904 & .463 \\
PCG II. 1/B & 42 & .0476 & .21554 & & \\
Total & 204 & .0294 & .16937 & & \\
\hline
\end{tabular}

As seen in the table, the distribution of the One-Way ANOVA test on the level of correct / incorrect use of semicolon by the students based on the student department variable revealed no significant 
difference between the correct semicolon use based on student department $(F(4,199)=.904 ; p=.463$, if p> 0.05 then $\mathrm{H}_{0}$ is accepted. Variances were not equal based on the Levene's test).

Whether the semicolon use differed by gender is presented in the table below. Based on the Levene's test, the variances of the two groups were equal. The results of the t-test are presented below:

Table 26. Comparison of semicolon use based on gender

\begin{tabular}{ccccccc}
\hline Group & $\mathrm{N}$ & $\overline{\mathrm{x}}$ & $\mathrm{S}$ & $\mathrm{t}$ & $\mathrm{df}$ & $\mathrm{p}$ \\
\hline Female & 147 & .0340 & .18188 & \multirow{2}{*}{.522} & 202 & .534 \\
Male & 57 & .0175 & .13245 & & & \\
\hline
\end{tabular}

No statistically significant difference was determined between the total number of correct semicolon use by female and male students based on t-test results conducted to compare semicolon use based on gender $(\mathrm{t}(202)=.622 ; \mathrm{p}=.534$, if $\mathrm{p}>0.05$ then $\mathrm{H} 0$ is accepted). Both group averages were similar and there was no difference between the genders based on correct semicolon use.

\subsection{Dash (一)}

All dashes used in the manuscript, which was the data collection instrument in the study, were used with the same function: to identify the quotations displayed at the beginning of a paragraph (Yazim K1lavuzu, 2012, p. 35). The total semicolon use by the students in the edited manuscript is presented in the table below:

Table 27. The total correct/incorrect dash use

\begin{tabular}{ccccccc}
\hline Correct / & Turkish & PCG I. 1/A & PCG I. 1/B & PCG II. 1/A & PCG II. 1/B & Total \\
Incorrect & $(\%)$ & $(\%)$ & $(\%)$ & $(\%)$ & $(\%)$ & $\begin{array}{c}(\%) \\
\text { Correct }\end{array}$ \\
\hline 3.08 & 0.88 & 1.49 & 1.23 & 1.61 & 1.66 \\
Incorrect & 96.92 & 99.12 & 98.51 & 98.77 & 98.39 & 98.34 \\
\hline
\end{tabular}

During the review of student manuscripts, use of quotation marks instead of a dash was considered correct and use of both marks was considered incorrect. Analysis of the study data demonstrated that dash use was very rare in the texts edited by the students. There was no student who used the dash correctly in all points. Certain students preferred quotation marks instead of dash, and certain others used neither a dash nor quotation marks. These students may not understand that the text included speech. However, also the number of students, who used both punctuation marks was quite high. This demonstrated that the functions of both the quotation mark and the dash were not fully known.

Findings on the sub-problem of whether there was a difference between dash use based on the student department in the manuscripts that the students edited are presented below: 
Table 28. One-Way ANOVA Comparison of Correct Dash Use Based on the Department Variable

\begin{tabular}{cccccc}
\hline Group & $\mathrm{N}$ & $\overline{\mathrm{x}}$ & $\mathrm{S}$ & $\mathrm{F}$ & $\mathrm{p}$ \\
\hline Turkish language & 39 & .2564 & .90954 & & \\
PCG I. 1/A & 47 & .0426 & .20403 & & \\
PCG I. 1/B & 36 & .1389 & .35074 & & \\
PCG II. 1/A & 40 & .0750 & .34991 & & \\
PCG II. 1/B & 42 & .0952 & .29710 & & \\
Total & 204 & .1176 & .48208 & & \\
\hline
\end{tabular}

As seen in the table, the distribution of the One-Way ANOVA test on the level of correct / incorrect use of dash by the students based on the student department variable revealed no significant difference between the correct dash use based on student department $\left(\mathrm{F}(4,199)=1.217 ; \mathrm{p}=.305\right.$, if $\mathrm{p}>0.05$ then $\mathrm{H}_{0}$ is accepted. Variances were not equal based on the Levene's test).

Whether the dash use differed by gender is presented in the table below. Based on the Levene's test, the variances of the two groups were equal. The results of the t-test are presented below:

Table 29. Comparison of dash use based on gender

\begin{tabular}{|c|c|c|c|c|c|c|}
\hline Group & $\mathrm{N}$ & $\overline{\mathrm{x}}$ & $S$ & $\mathrm{t}$ & df & $\mathrm{p}$ \\
\hline Female & 147 & .1429 & .54897 & \multirow{2}{*}{1.664} & \multirow{2}{*}{201.343} & \multirow{2}{*}{.098} \\
\hline Male & 57 & .0526 & .22528 & & & \\
\hline
\end{tabular}

No statistically significant difference was determined between the total number of correct dash use by female and male students based on t-test results conducted to compare dash use based on gender $\left(\mathrm{t}(201,343)=1.664 ; \mathrm{p}=.098\right.$, if $\mathrm{p}>0.05$ then $\mathrm{H}_{0}$ is accepted). Both group averages were similar and there was no difference between the genders based on correct dash use.

The overall findings obtained in the present study that was conducted to determine the knowledge levels of freshmen college students on punctuation mark use are presented in Table 30:

Table 30. Overall study findings

\begin{tabular}{ccccccc}
\hline & $\begin{array}{c}\text { Turkish } \\
\text { Language }(\%)\end{array}$ & $\begin{array}{c}\text { PCG I. } \\
\text { 1/A }(\%)\end{array}$ & $\begin{array}{c}\text { PCG I. } \\
\text { 1/B }(\%)\end{array}$ & $\begin{array}{c}\text { PCG II. } \\
1 / \mathrm{A}(\%)\end{array}$ & $\begin{array}{c}\text { PCG II. } \\
1 / \mathrm{B}(\%)\end{array}$ & $\begin{array}{c}\text { Total } \\
(\%)\end{array}$ \\
\hline Period & 68.95 & 62.40 & 65.56 & 65.52 & 66.93 & 65.87 \\
Comma & 16.44 & 10.87 & 14.93 & 13.96 & 13.53 & 13.95 \\
Question mark & 87.95 & 85.85 & 83.95 & 88.75 & 80.95 & 85.49 \\
$\begin{array}{c}\text { Exclamation } \\
\text { point }\end{array}$ & 18.75 & 25.08 & 28.13 & 20.48 & 18.75 & 22.24 \\
$\begin{array}{c}\text { Quotation mark } \\
\text { Colon }\end{array}$ & 34.25 & 23.88 & 27.97 & 28.95 & 26.87 & 28.38 \\
& 24.25 & 20.19 & 20.91 & 22.29 & 22.31 & 21.99
\end{tabular}




\begin{tabular}{ccccccc} 
Semicolon & 0 & 2.95 & 0 & 5.45 & 3.2 & 2.32 \\
Dash & 3.08 & 0.88 & 1.49 & 1.23 & 1.61 & 1.66 \\
\hline
\end{tabular}

As seen in the table, it was found that the participating students could place only period and question mark correctly over $50 \%$ of the points where these marks were originally used in the manuscript. The highest correct use was $85.49 \%$ in the question mark and the lowest correct use was $1.66 \%$ in dash. In two classes, none of the students used the semicolon correctly.

\subsection{Punctuation mark use based on the department variable}

The arithmetic mean of correct punctuation mark use was also investigated based on the presence of a statistically significant difference between the student departments. The similarity between the student knowledge and skill levels was measured to improve the reliability of the study. The aggregate findings of the One-Way ANOVA conducted for this purpose are presented in Table 31.

Table 31. The findings on the sub-problem "Is there a difference between knowledge of the students on punctuation marks based on student department?"

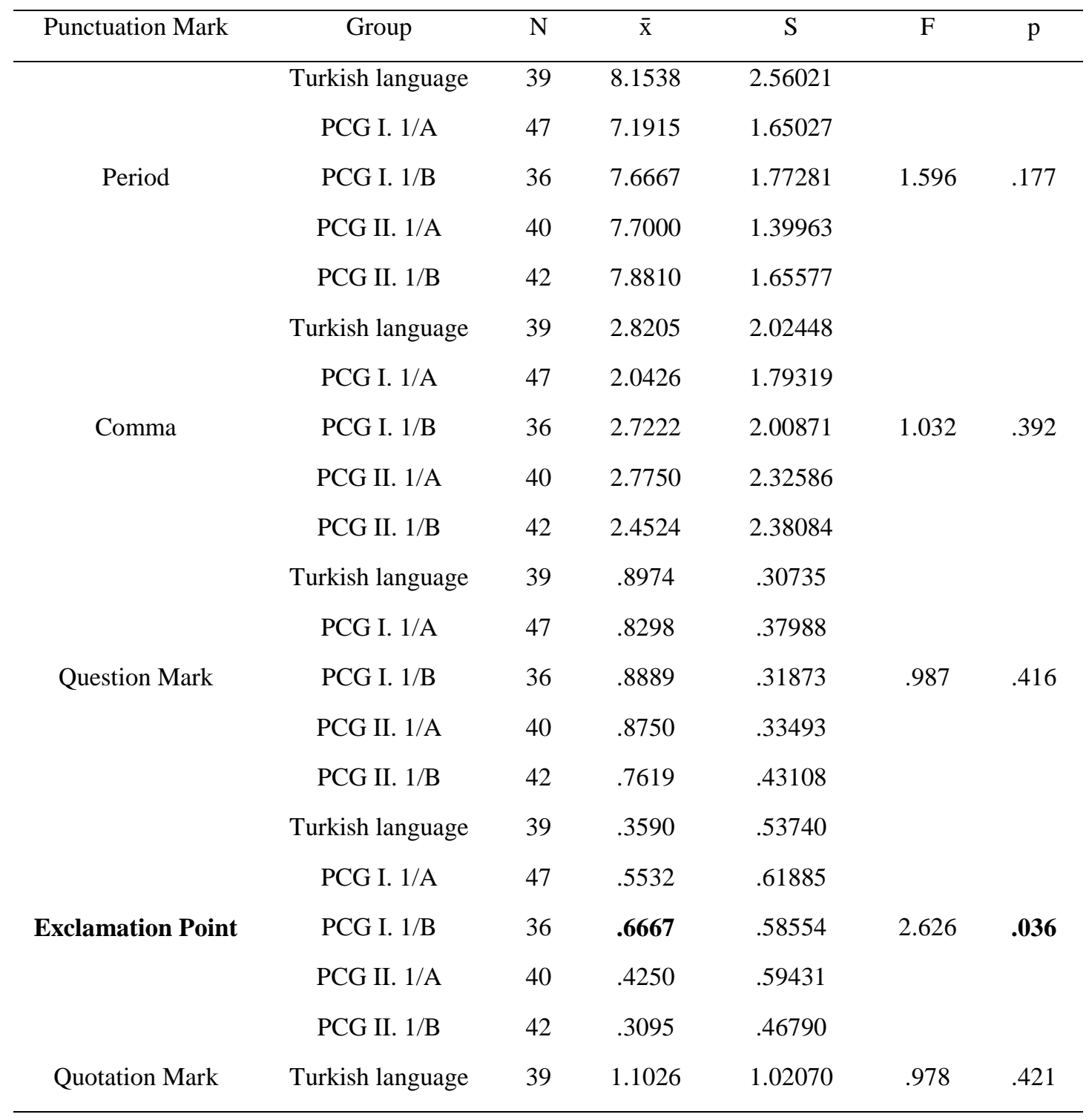




\begin{tabular}{|c|c|c|c|c|c|c|}
\hline & PCG I. 1/A & 47 & .8298 & .84233 & & \\
\hline & PCG I. 1/B & 36 & 1.0278 & .87786 & & \\
\hline & PCG II. 1/A & 40 & .8500 & .76962 & & \\
\hline & PCG II. 1/B & 42 & .8095 & .70670 & & \\
\hline \multirow{5}{*}{ Colon } & Turkish language & 39 & 1.2308 & .95866 & \multirow{5}{*}{.592} & \multirow{5}{*}{.669} \\
\hline & PCG I. 1/A & 47 & .9787 & 1.01058 & & \\
\hline & PCG I. 1/B & 36 & 1.2778 & 1.00317 & & \\
\hline & PCG II. 1/A & 40 & 1.1500 & 1.05125 & & \\
\hline & PCG II. 1/B & 42 & 1.0714 & 1.02154 & & \\
\hline \multirow{5}{*}{ Semicolon } & Turkish language & 39 & .0000 & .00000 & \multirow{5}{*}{.904} & \multirow{5}{*}{.463} \\
\hline & PCG I. 1/A & 47 & .0426 & .20403 & & \\
\hline & PCG I. 1/B & 36 & .0000 & .00000 & & \\
\hline & PCG II. 1/A & 40 & 0.500 & .22072 & & \\
\hline & PCG II. 1/B & 42 & .0476 & .21554 & & \\
\hline \multirow{5}{*}{ Dash } & Turkish language & 39 & .2564 & .90954 & \multirow{5}{*}{1.217} & \multirow{5}{*}{.305} \\
\hline & PCG I. 1/A & 47 & .0426 & .20403 & & \\
\hline & PCG I. 1/B & 36 & .1389 & .35074 & & \\
\hline & PCG II. 1/A & 40 & .0750 & .34991 & & \\
\hline & PCG II. 1/B & 42 & .0952 & .29710 & & \\
\hline
\end{tabular}

Review of the distribution that demonstrated One-Way ANOVA comparisons on correct punctuation mark use based on the department variable demonstrated that there was no significant difference between correct punctuation mark use except the exclamation point based on the student department variable. Test results demonstrated at least one of the group scores was different. To determine this group, Tukey HSD test was conducted, and the findings demonstrated that there was a significant difference between correct exclamation point use levels of PDR I. 1 / B and PDR II. 1 / B departments (classes), and PDR I. 1 / B class average was higher than that of PDR II. 1 / B class. This finding demonstrated that student knowledge levels on punctuation marks were similar.

\subsection{Punctuation mark use based on gender variable}

The results of the Independent Samples t-Test conducted to determine whether the correct use of punctuation marks statistically significantly differed by gender are as follows: 
Table 32. The findings on the sub-problem "Is there a difference between knowledge and skill levels of the students on punctuation marks based on gender?"

\begin{tabular}{|c|c|c|c|c|c|c|c|}
\hline $\begin{array}{l}\text { Punctuation } \\
\text { Mark }\end{array}$ & Group & $\mathrm{N}$ & $\overline{\mathrm{x}}$ & S & $\mathrm{T}$ & $\mathrm{df}$ & $\mathrm{p}$ \\
\hline \multirow{3}{*}{ Period } & Female & 147 & 7.6531 & 1.80810 & \multirow{3}{*}{-.593} & \multirow{3}{*}{202} & \multirow{3}{*}{.554} \\
\hline & & & & & & & \\
\hline & Male & 57 & 7.8246 & 1.96508 & & & \\
\hline \multirow{3}{*}{ Comma } & Female & 147 & 2.6531 & 2.10236 & \multirow{3}{*}{1.237} & \multirow{3}{*}{202} & \multirow{3}{*}{.217} \\
\hline & & & & & & & \\
\hline & Male & 57 & 2.2456 & 2.13207 & & & \\
\hline \multirow{3}{*}{ Question Mark } & Female & 147 & .8367 & .37087 & \multirow{3}{*}{-.720} & \multirow{3}{*}{202} & \multirow{3}{*}{.473} \\
\hline & & & & & & & \\
\hline & Male & 57 & .8772 & .33113 & & & \\
\hline \multirow{2}{*}{$\begin{array}{c}\text { Exclamation } \\
\text { Point }\end{array}$} & Female & 147 & .4830 & .58933 & \multirow{2}{*}{.888} & \multirow{2}{*}{202} & \multirow{2}{*}{.375} \\
\hline & Male & 57 & .4035 & .52981 & & & \\
\hline \multirow{3}{*}{ Quotation Mark } & Female & 147 & .9932 & .85605 & \multirow{3}{*}{2.090} & \multirow{3}{*}{202} & \multirow{3}{*}{.038} \\
\hline & & & & & & & \\
\hline & Male & 57 & .7193 & .79629 & & & \\
\hline \multirow{3}{*}{ Colon } & Female & 147 & 1.1701 & .98880 & \multirow{3}{*}{.859} & \multirow{3}{*}{202} & \multirow{3}{*}{.391} \\
\hline & & & & & & & \\
\hline & Male & 57 & 1.0351 & 1.05161 & & & \\
\hline \multirow{3}{*}{ Semicolon } & Female & 147 & .0340 & .18188 & \multirow{3}{*}{.622} & \multirow{3}{*}{202} & \multirow{3}{*}{.534} \\
\hline & & & & & & & \\
\hline & Male & 57 & .0175 & .13245 & & & \\
\hline \multirow{3}{*}{ Dash } & Female & 147 & .1429 & .54897 & \multirow{3}{*}{1.664} & \multirow{3}{*}{201.343} & \multirow{3}{*}{.098} \\
\hline & & & & & & & \\
\hline & Male & 57 & . 0526 & .22528 & & & \\
\hline
\end{tabular}

The t-test was used to compare the total number of correct punctuation mark use by female and male students and the results demonstrated that there was no statistically significant difference between correct punctuation mark use by female and male students except the quotation marks. Only the correct quotation mark use level was slightly higher among female students. This finding demonstrated that the knowledge of both female and male students on punctuation marks was similar. 


\section{Results}

Analysis of the reasons for using the punctuation marks correctly or incorrectly demonstrated that the students made mistakes mostly in complex sentences and sentences that lack a clear clue about the punctuation marks. Students used correct punctuation marks in simple sentences and sentences that included clear clues about the required punctuation marks. During education before higher education and in exercises included in textbooks, the points that require a punctuation mark are indicated by parentheses. In other words, the students are not trained and evaluated based on the texts they write, multiple choice questions where the points that require a punctuation mark are indicated by parentheses are utilized. This restricts the punctuation marks to remain at the knowledge level, leading to student mistakes in open ended questions and cases that require creativity.

Although students used punctuation marks in the manuscripts they edited, they used a very few correctly. This finding demonstrated that students had incomplete or incorrect knowledge on punctuation marks and their functions.

Another general problem was the comprehension of compound sentences. Instead of separating the compound sentences with a comma, students considered it as a full sentence and used a period. This finding demonstrated that the sentence knowledge levels of the students were inadequate.

The students experienced the highest number of problems with dash $(2.32 \%)$ and semicolon $(1.66 \%)$. The high rate of mistakes in these punctuation marks was due to the fact that the students used quotation marks instead of a dash and comma instead of a semicolon. This suggested that the knowledge of the students on the functions of punctuation marks was insufficient.

It was determined that freshmen college students in the present study scored worse (28.38\%) in using the correct quotation mark when compared to primary school first grade students in the USA $(52.9 \%)$ as reported by Cordeiro, Giacobbe, and Cazden (1983).

The students made the least number of mistakes when using the question mark (85.49\%). The students mostly used the question mark correctly; however, they also used a question mark in the sentence that included a word indicating a question but was not a question sentence. This led to a higher error rate in exclamation point use (22.24\%). This demonstrated that certain students did not know that the question mark could only be placed at the end of a sentence which includes a question.

There was no significant difference between the punctuation mark use by the secondary education students, whose university entrance scores are lower, and first education students.

A significant difference was determined between the quotation mark use by the female and male students favoring the females (.038). This demonstrated that there was no difference between the general use of punctuation marks based on gender. However, in a study conducted by Ozkara and Izci (2013) on $5^{\text {th }}$ grade students, in 7 of the 13 punctuation marks used in the study, there was a significant correlation between correct punctuation mark use based on gender [point: $(\mathrm{X} 2(3)=9.305 ; \mathrm{p}<0.05)$, comma: $\left(X^{2}(3)=19.439 ; p<0.05\right)$, exclamation point: $\left(X^{2}(3)=8.262 ; p<0.05\right)$, quotation mark: $\left(X^{2}\right.$ $(3)=12.875 ; p<0.05)$, apostrophe: $\left(X^{2}(3)=15.858 ; p<0.05\right)$, dash: $\left(X^{2}(3)=8.338 ; p<0.05\right)$, ditto marks: $\left.\left(X^{2}(3)=9.347 ; p<0.05\right)\right]$ favoring the females. Thus, there were similarities between Ozkara and Scout's findings based on quotation mark use and differences based on other marks. This finding could be interpreted as the difference between genders decreased as the age and education level of the students increased. For more reliable results, further studies on the correlation between gender variable and age and education level should be conducted. 


\section{Discussion}

Results from the study are discussed, explained, and interpreted in the part. According to this study providing students with a manuscript that did not include punctuation marks demonstrated their reading comprehension and interpretation skills and ability to edit the text with correct punctuation marks based on essay writing rules. This caused students to experience the same difficulties that the initials users of punctuation marks who invented them. Poor student skills in using punctuation marks could be due to providing students a manuscript written by someone else instead of allowing them to write a manuscript. This finding was in support of the views of Huguet, (1946), Baron (2001) and Egbert (1896), who argued that punctuation marks are used to separate the expressions and sections in manuscripts.

Punctuation marks are directly associated with the meaning of the text. Individuals who cannot comprehend the text are not expected to use correct punctuation marks. The present study findings demonstrated that freshmen college students experienced reading comprehension problems. This finding was consistent with the low scores by Turkish students (428) that was lower than all mean scores of other nations (460) in PISA 2015 report (T.R. Ministry of Education, General Directorate of Evaluation and Examination Services, 2016).

The present study findings demonstrated that the students did not learn knowledge on punctuation marks that should be learned during primary and secondary education and cannot use the punctuation marks when required. These findings demonstrated that the majority of freshmen college students experienced difficulties in correctly using the punctuation marks included in the curriculum. This finding was consistent with the study findings reported by Avc1 (2006), Bagci (2011), Ekinci Celikpazu (2006), Kirbas (2006), Ozkara and Izci (2013), Topuz (2008), Uludag (2002) and Yildiz (2002).

In a study conducted by Karagül (2010) on primary education 6th, 7th and $8^{\text {th }}$ grade students, it was also found that students scored poorly on punctuation marks. Karagul suggested that this was due to insufficient punctuation marks content in the textbook used in the course. Although the punctuation marks and which punctuation marks should be instructed in which grade were specified in the curriculum, it could be suggested that the problem was due to the teachers and utilized instructional methods and techniques. The main reason should be determined in a future comprehensive study.

In order to improve student level in punctuation marks, it may be recommended to make the students active and to instruct the topic of punctuation marks by allowing the students to discover the topic using applications instead of conventional instruction since the discovery approach is a motivating strategy based on student activity, which allows reaching abstractions by collecting and analysing data about a particular problem (Bilen, 2006). Sahin, Maden, Kardas and Sahin (2014) reported that the use of group research technique improved student achievements in punctuation marks.

\section{Conclusions}

Review of primary and middle school textbooks demonstrated that they lacked educational activities that would allow the students to learn punctuation marks and their functions and attract different types of intelligence. When it is considered that students have different intelligence areas in education, the retention of knowledge should be increased through activities that could address various intelligence areas. Parentheses used in reinforcing work, measurement and evaluation questions in the textbooks, and the questions included in the university admission exams that indicate where the punctuation marks should be used should not be included and the students should find where to use the punctuation marks without a clue. Furthermore, the knowledge of the students on punctuation marks should be measured using the texts written by the students. 


\section{Ethics Committee Approval}

The author(s) confirm(s) that the study does not need ethics committee approval according to the research integrity rules in their country. (Date of Confirmation: June 11, 2020)

\section{Acknowledgements}

This article was presented orally at III International Educational Sciences and Social Sciences Symposium held in Nevsehir on March 25-27, 2019.

\section{References}

Applebee, A. N., Langer, J. A., \& Mullis I. V. S., (1987). Grammar, punctuation, and spelling: controlling the conventions of written English at ages 9, 13, and 17. Princeton, NJ: National Assessment of Educational Progress.

Ari, G., \& Keray, B. (2012). 8th grade students' level of using punctuation marks. Electronic Journal of Social Sciences, 11(42), 40-54. Retrieved on April 8, 2019 from: http://www.esosder.org/eng/?sayfa=ozet\&no=986

Atasoy, F. O. (2010). The History of Punctuation Marks. Turkish Studies, 5(2), 823-861. DOI: 10.7827/TurkishStudies.1345

Avci, E. (2006). Examining of written expression falses having been done by 8th class students of primary education (Sample of Muğla). (Unpublished MA thesis). Ankara University, Turkey.

Bagci, H. (2011). Elementary 8th Grade Student's Level of Ability to Apply Spelling Rules and Punctuation Marks. Turkish Studies, 6(1), 693-706. DOI: 10.7827/TurkishStudies.1973

Baron, N. S. (2001). Commas and canaries: The role of punctuation in speech and writing. Language Sciences, 23, 15-67. DOI: 10.1016/S0388-0001(00)00027-9

Best, J.W. (1959). (1970. Research in education (2nd ed.). Prentice Hall.

CNNTurk.com, (2018, August 1). Turkiye Haberleri. Retrieved on October 22, 2019 from: https://www.cnnturk.com/turkiye/yksde-41-bin-aday-sifir-cekti-adaylar-en-cok-turkcede-basarilioldu

Cordeiro, P., Giacobbe, M., \& Cazden, C. (1983). Apostrophes, quotation marks, and periods: Learning punctuation in the first grade. Language Arts, 60(3), 323-332. Retrieved on March 5, 2018 from: http://www.jstor.org/stable/41962390

Cetin, A. (2013). Kur'an Ilimleri ve Kur'an-ı Kerim Tarihi. Istanbul: Dergâh Publication.

Egbert, J. C. (1896). Introduction to the study of Latin inscriptions (2nd ed.). New York: American Book Company.

Ekinci Celikpazu, E. (2006). A study on 6th grade primary students writing skills in Erzurum city centre. (Unpublished MA thesis). Atatürk University, Erzurum.

Gabain, A. von. (1988). Eski Turkcenin grameri, (Trans: Mehmet Akalin). Ankara: Ataturk Culture Language History Supreme Council Publications.

Hengirmen, M. (2007). Turkce dil bilgisi (9th ed.). Ankara: Engin Publication. 
Huguet, P. B. (1946). Epigrafia Latina. Barcelona: Publicaciones de la Escuela de Filologia.

Karagul, S. (2010). Application level of the noted writing and its rules in Turkish lesson teaching programme of the elementary 6-8. class students. (Unpublished MA thesis). Dokuz Eylül University, İzmir.

Kurbas, A. (2006). The evaluation of writing abilities of primary education's eight class students. (Unpublished MA thesis). Atatürk University, Erzurum.

Oguzkan, A. (2005). Orneklerle Turkce ve kompozisyon bilgileri. Istanbul: Inkilap Bookstore.

Ozkara, Y. \& Izci G. (2013). Ilkögretim 5. sinif ögrencilerinin okumaya yonelik tutumlari ile noktalama isaretlerini uygulama duzeyleri arasindaki iliskinin incelenmesi. Cumhuriyet International Journal of Education-CIJE, 2(2), 1-9. Retrieved on March 26, 2019 from: https://dergipark.org.tr/download/article-file/48663

Parkes, M. B. (2016). Pause and effect: An introduction to the history of punctuation in the west. New York: Routledge.

Repuclic of Turkey Ministry of National Education, Board of Education and Training (2018). Turkish Language Teaching Program (Primary and Secondary School 1, 2, 3, 4, 5, 6, 7 and 8. Grades). Retrieved on March 30, 2019 from: http://mufredat.meb.gov.tr/ProgramDetay.aspx?PID=663

Repuclic of Turkey Ministry of National Education, General Directorate of Measurement, Evaluation and Examination Services (2016). PISA 2015 national report. Retrieved on October 21, 2018 from: http://odsgm.meb.gov.tr/test/analizler/docs/PISA/PISA2015_Ulusal_Rapor.pdf

Rummel, J. F. (1968). An introduction to research procedures in education (2nd ed.) San Francisco: Harper and Row.

Saenger, P. (1997). Space between words: The origin of silent reading. Stanford: Stanford University Press.

Sahin, E, Maden, S, Kardas, M., \& Sahin, A. (2014). The influence of group research technique on student achievement in the teaching of punctuation marks. Mustafa Kemal University Journal of Social Sciences Institute, 8(15), 257-268. Tekin, T. (1997). Tarih boyunca Türkçenin yazımı. Ankara: Simurg Publication.

Thompson, E. M. (1912). An introduction to Greek and Latin palaeography. Oxford: Clarendon Press.

Topuz, A. (2008). The study of knowledge and skill levels of sixth and seventh grady students in Sivasli Usak. (Unpublished doctoral dissertation). Afyon Kocatepe University, Afyon, Turkey.

Uludag, E. (2002). Students' skill fullness in use of syntax and punctation in middle school grades. Erzincan University Journal of Education Faculty, 4(1), 97-114. DOI: 10.17556/jef.72765

Vatkins, T. (2017), "History of the Punctuation of English Writing". Retrieved on February 03, 2019 from: http://www.sjsu.edu/faculty/watkins/punctuation.htm

Wingo, E. Otha (1972). Latin punctuation in the classical age. The Hague: Mouton.

Yildirim, D., \& Uludag, E. (2016). Determine the level of using the orthography and punctuation by the students at the second level of primary school (Istanbul Sample). Erzincan University Journal of Education Faculty 18(1) 319-342. DOI: 10.17556/jef.72765

Yildiz, N. (2003). Kalıntılar ve edebi kaynaklar isiginda antikçag kutuphaneleri. Istanbul: Archeology and Art Publication. 
Yildiz, Z. (2002). The practising levels of students at different teaching levels for orthography and punctuation rules. (Unpublished MA Thesis). Suleyman Demirel University, Turkey.

\section{Üniversite 1. sınıf öğrencilerinin noktalama işaretleri konusundaki bilgi düzeyleri üzerine bir araştırma}

\section{$\ddot{O} \mathbf{z}$}

$\mathrm{Bu}$ araştırma, ana dili Türkçe olan üniversite 1. Sınıf öğrencilerinin Türkçedeki noktalama işaretleri kullanım durumlarını tespit etmek için yapılmıştır. Araştırma nicel yöntemle hazırlanmış, betimleme teknikleri kullanılmıştır. Araştırmanın çalışma grubunu 157'si kız, 57'si erkek olmak üzere 204 öğrenci oluşturmaktadır. Veri toplama aracı olarak, noktalama işaretleri kaldırılmış, anonim bir kısa hikâye metni kullanılmıştır. Orijinal metinde farklı sayıda kullanılmış 8 noktalama işareti vardır. Veriler, öğrencilere dağıtılan değiştirilmiş metni kompozisyon kuralları çerçevesinde yeniden oluşturmaları istenerek elde edilmiştir. Verilerin analizleri için IBM SPSS Statictics 22 programında T-Testi, One-Way ANOVA, Tukey HSD testleri kullanılmıştır. Sonuçlara göre, öğrencilerin bütün noktalama işaretlerinde çok sayıda hata yaptığı bulunmuştur. Öğrencilerin çoğunluğu tarafından doğru kullanılan tek noktalama işareti noktadır. En çok yanlış ise 98,34 oranıyla uzun çizgide yapılmıştır. Bulgular, bölümlere göre incelendiğinde sadece PDR I. öğretim 1/B ve PDR II. öğretim 1/B şubelerinde, ünlem işareti kullanımında farklılık vardır. Cinsiyetlere göre sadece tırnak işareti kullanımında kızlar lehine anlamlı bir farklılık bulunmuştur.

Anahtar sözcükler: noktalama işaretleri; üniversite 1. sınıf öğrencileri; noktalama işaretleri bilgi düzeyi; yazma becerisi; Türkçe öğretimi.

\section{AUTHOR BIODATA}

Yusuf Sülükçü received his doctorate degree in Selcuk University, Institute of Education Sciences, Department of Turkish Language Education. His research fields include instruction of Turkish as a native language and as a foreign language. Currently, he works as an associate professor at Necmettin Erbakan University, Faculty of Education, Department of Turkish Language Education.

Ayşe Kırboğa completed her undergraduate and master's degree education at Necmettin Erbakan University, Institute of Education Sciences, Department of Turkish Language Education. Her research fields include instruction of Turkish as a native language. Currently, she works as a teacher at Minister of National Education, Kayalı Middle School. 